\title{
Article \\ The Effects of a Gum Arabic-Based Edible Coating on Guava Fruit Characteristics during Storage
}

\author{
Sherif Fathy El-Gioushy 1,*(D), Mohamed F. M. Abdelkader ${ }^{2}$, Mohamed H. Mahmoud ${ }^{3}$ (D), Hanan M. Abou El Ghit ${ }^{4}$,

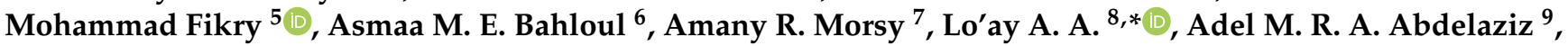 \\ Haifa A. S. Alhaithloul ${ }^{10}$, Dalia M. Hikal 11 (D), Mohamed A. Abdein 12,*(D), Khairy H. A. Hassan ${ }^{13}$ \\ and Mohamed S. Gawish ${ }^{14}$ (i)
}

Citation: El-Gioushy, S.F.; Abdelkader, M.F.M.; Mahmoud, M.H.; Abou El Ghit, H.M.; Fikry, M.; Bahloul, A.M.E.; Morsy, A.R.; A., L.A.; Abdelaziz, A.M.R.A.; Alhaithloul, H.A.S.; et al. The Effects of a Gum Arabic-Based Edible Coating on Guava Fruit Characteristics during Storage. Coatings 2022, 12, 90. https:// doi.org/10.3390/coatings12010090

Academic Editor: Lili Ren

Received: 2 December 2021

Accepted: 7 January 2022

Published: 13 January 2022

Publisher's Note: MDPI stays neutral with regard to jurisdictional claims in published maps and institutional affiliations.

Copyright: (c) 2022 by the authors. Licensee MDPI, Basel, Switzerland. This article is an open access article distributed under the terms and conditions of the Creative Commons Attribution (CC BY) license (https:// creativecommons.org/licenses/by/ $4.0 /)$.
1 Horticulture Department, Faculty of Agriculture (Moshtohor), Benha University, Benha 13736, Egypt

2 Department of Plant Production, College of Food and Agriculture, King Saud University, Riyadh 12372, Saudi Arabia; mohabdelkader@ksu.edu.sa

3 Department of Biochemistry, College of Science, King Saud University, Riyadh 11451, Saudi Arabia; mmahmoud2@ksu.edu.sa

4 Botany and Microbiology Department, Faculty of Science, Helwan University, Cairo 11795, Egypt; hanan8760@yahoo.com

5 Department of Agricultural and Biosystems Engineering, Faculty of Agriculture, Benha University, Moshtohor 13736, Egypt; moh.eltahlawy@fagr.bu.edu.eg

6 Department of Agricultural Economics, Faculty of Agriculture, Banha University, Banha 13736, Egypt; asmaa.bahlol@fagr.bu.edu.eg

7 Plant Protection Department, Faculty of Agriculture, Benha University, Benha 13736, Egypt; amani.alzoheri@fagr.bu.edu.eg

8 Pomology Department, Faculty of Agriculture, Mansoura University, Mansoura 35516, Egypt

9 Central Lab. of Organic Agriculture, Agriculture Research Center, Giza 12411, Egypt; dr.adel.organic@gmail.com

10 Biology Department, Collage of Science, Jouf University, Sakaka 72388, Saudi Arabia; haifasakit@ju.edu.sa

11 Nutrition and Food Science, Home Economics Department, Faculty of Specific Education, Mansura University, Mansoura 35516, Egypt; dr.daliahikal@mans.edu.eg

12 Biology Department, Faculty of Arts and Science, Northern Border University, Rafha 91911, Saudi Arabia

13 Tropical Fruits Research Department, Horticulture Research Institute, Agricultural Research Centre, Giza 12619, Egypt; kh11191@ymail.com

14 Pomology Department, Faculty of Agriculture, Damietta University, Damietta 34511, Egypt; msagawishaa@gmail.com

* Correspondence: sherif.elgioushy@fagr.bu.edu.eg (S.F.E.-G.); Loay_Arafat@mans.edu.eg (L.A.A.); abdeingene@yahoo.com (M.A.A.)

\begin{abstract}
Guava is a nutritious fruit that has perishable behavior during storage. We aimed to determine the influences of some edible coatings (namely, cactus pear stem (10\%), moringa (10\%), and henna leaf $(3 \%)$ extracts incorporated with gum Arabic $(10 \%))$, on the guava fruits' properties when stored under ambient and refrigeration temperatures for 7, 14, and 21 days. The results revealed that the coating with gum Arabic (10\%) only, or combined with the natural plant extracts, exhibited a significant reduction in weight loss, decay, and rot ratio. Meanwhile, there were notable increases in marketability. Moreover, among all tested treatments, the application of gum Arabic (10\%) + moringa extract $(10 \%)$ was the superior treatment for most studied parameters, and exhibited for the highest values for maintaining firmness, total soluble solids, total sugars, and total antioxidant activity. Overall, it was suggested that coating guava with $10 \%$ gum Arabic combined with other plant extracts could maintain the postharvest storage quality of the cold-storage guava.
\end{abstract}

Keywords: guava; edible coating; gum Arabic; natural plant extracts; storability

\section{Introduction}

Guava (Psidium guajava L.) is a popular fruit with a climacteric nature feature. It has a relatively short shelf life (3-4 days) at tropical ambient temperature $\left(28 \pm 2{ }^{\circ} \mathrm{C}\right)$, due to its 
physiology, disorder, postharvest infection, and aging [1,2]. The stability of guava could be influenced by numerous factors, such as storage temperatures, relative humidity, packaging materials, and coating nature [3,4]. Producers of guava fruits store them in traditional packs, such as paper and/or plastic materials. Although these packaging materials present some merits, they could cause severe environmental difficulties because they are non-recyclable and nonedible resources [4-6].

Physiologically, guava is a climacteric fruit with high inhalation and transpiration degrees that are analogous to different products such as bananas [5] and mushrooms [7]. This creates the need to develop novel technologies for extending its shelf life [8], providing better storage conditions, and enhancing its visual features.

The edible coatings are applied directly on the surface of the fruit, consisting of thin membranes, invisible to the naked eye. They can carry natural additives and are important in extending the shelf life of foods, as they enhance the protective action of the fruit epidermis in preventing water loss, color changes, mechanical lesions and even microbial deterioration, and generally give surface glossy appearance [3,9]. Such technology has exposed a great possibility with low cost and proper features for related usage in food plants.

Previously, edible coatings were fabricated from biomaterials-namely polysaccharides, proteins and lipids - and their results were utilized to formulate edible coatings [10]. Formerly, coating materials efficiently prolonged a fruit's shelf-life, and increased the consumers' health and environment. Numerous studies have reported the efficiency of edible coatings in expanding the shelf-life of different kinds of fruits by decreasing their weight loss [10,11], respiration [12,13], oxidative reaction rates [14], and physiological disorders [15]. Edible coatings are an excellent alternative to chemical preservation [16].

Among the natural polymers used to formulate edible coatings, gum Arabic (GA) and cactus pear extract have been deemed the most promising materials, mostly because their high accessibility, low price, and good performance. However, their high hydrophilicity permits $\mathrm{H}_{2} \mathrm{O}$ to easily form. GA is one of the ecological biopolymers acquired from the branches and stems of Acacia trees (Acacia spp.). It is comprised of rhamnose, galactose, arabinose, and glucuronic acid with $\mathrm{Ca}, \mathrm{Mg}$, and $\mathrm{K}$ ions $[17,18]$. In addition, GA is commercially and securely utilized as a food additive, due to its film shaping, emulsification, and encapsulation attributes $[18,19]$.

Numerous studies have been conducted on the application of GA for nullity purposes, such as its ability to postpone the physicochemical alterations of bananas during cold storage [20], and minimize the fungal infection of anthracnose on banana and papaya fruits [20]. GA coatings have efficiently kept the antioxidative polyphenols of tomatoes [21] and papayas [22], and lowered browning, vitamin C, and the polyphenols of cold-stored mangos [23]. Moreover, GA-coating significantly decreases weight loss, chilling damage, membrane leakage, and decay prevalence, with slight increases in total soluble solids, $\mathrm{pH}$, and sugar $[24,25]$.

M. oleifera is widely in demand for its nutritional and medicinal properties, due to its content of vitamins B and C, amino acids, crude protein, and its low anti-nutritional and antimicrobial agents with film organic and shelf-life-boosting properties [26-28]. Moreover, its extracts have been utilized to formulate the coating that effectively preserves the postharvest quality of citrus fruit [29]. Moringa extract maintains postharvest quality, keeping and elongating the shelf life of avocado fruit by lowering respiration, ethylene production rates and higher firmness during storage [28,30,31]. It also significantly inhibits (30-33\%) radial mycelial growth of the pathogen with a combination of GA edible coatings with moringa leaf extract. There is evidence for the incorporation of moringa leaf extract with edible coatings improving antimicrobial activity $[32,33]$.

The mucilage films from the cactus pear plant prolong shelf life and maintain guava quality attributes. Further research is wanted to realize whether mucilage is possible for use as an edible film under cold storage [28]. In guava and cactus pear, the film prolonged the fruit's skin color and retained superior total soluble solids concentration (TSSC), firmness 
(F), and dry matter concentration (DMC), lowered the fruit's weight loss and prolonged its skin color. Firmness, TSSC, and DMC of fruit were comparable among treatments [34].

Henna (Lawsonia inermis) leaf extracts are a natural plant product with a projecting function against pathogens. Their expansion and propagation inhibit toxic activity [35].

There were no experiments undertaken to estimate the impact of combining the GA with each of the leaf extracts of Moringa, cactus pear, and Henna plants, in prior ediblecoating investigations. Therefore, this study aimed to investigate the effects of edible coatings based on GA with cactus pear, moringa, and Henna leaf extract on the storability and shelf life of guava.

\section{Materials and Methods}

\subsection{Fruit Materials}

The guava trees were grown in a commercial orchard in El-Qalubia Governorate, Egypt (latitude, $30^{\circ} 17^{\prime \prime} \mathrm{N}$ and longitude, $31^{\circ} 20^{\prime \prime} \mathrm{E}$ ). The trees were about 12 years of age and planted at a space of $5 \times 5 \mathrm{M}$ apart in loamy clay soil under an immersion irrigation system and subjected to all ideal agriculture traditions. The maturity stage (yellowishgreen), was the second week of August based on Mercado-Silva et al. [36], the trees and guavas were similar in size and free of obvious signs of infection.

\subsection{Postharvest Treatments and Storage}

The current study was performed during two seasons, 2020 and 2021, at the laboratory of the Department of Horticultural Crops Technology, National Research center, Giza, Egypt. Fine-feature guava fruits of the "Maamoura" cultivar, that were deep green color, uniform size, firm, and free from blemishes and mechanical damage, were harvested.

\subsection{Preparation of Plant Extracts}

Cactus pear stems were skinned and chopped. Samples were steamed with $\mathrm{H}_{2} \mathrm{O}$ in the ratio of 1:10 in an autoclave at $160^{\circ} \mathrm{C}$ for $1 \mathrm{~h}$. The boiled pulp was filtered and cooled. The slurry was centrifuged for $10 \mathrm{~min}$ and the supernatant gained was utilized as a coating substance (cactus pear mucilage). The filtrate (pulping liquor) was also utilized as a coating solution. Polyethylene glycol of molecular weight 2000 as plasticizer was mixed to the coating solution $5 \% w / v$. The $\mathrm{pH}$ value of this solution was modified at 7 , using small drops of ammonia solution.

Moringa leaf extract was made by soaking $100 \mathrm{~g}$ of air-dried moringa leaves in $1 \mathrm{~L}$ of $\mathrm{dH}_{2} \mathrm{O}$ for $24 \mathrm{~h}$. Then, it was diluted after being filtered with $\mathrm{H}_{2} \mathrm{O}$. Concentrations of $20 \%$

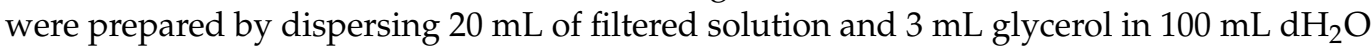
in a beaker.

GA powder of food-grade was acquired from Sigma Co., Cairo, Egypt. GA solution at $10 \%(w / v)$ was arranged by dissolving $500 \mathrm{~g}$ of GA powder in $5 \mathrm{~L}$ of $\mathrm{dH}_{2} \mathrm{O}$. The solution of GA was agitated with low heat at $40^{\circ} \mathrm{C}$ for $60 \mathrm{~min}$, using a hot plate with a magnetic stirrer (Model: 502P-2 USA), then filtered using a muslin cloth to eliminate impurities and any nameless materials. After cooling the solution to $20^{\circ} \mathrm{C}$, glycerol monostearate at $1 \%$ was mixed as a plasticizer to increase the intensity and elasticity of the coating solution. The $\mathrm{pH}$ of the solution was altered to 5.6 with $1 \mathrm{~N} \mathrm{NaOH}$ using a digital pH-meter (Model: AD1000, Bucharest, Romania). Then, $3 \%$ Henna was formulated; we soaked $100 \mathrm{~g}$ of air-dried henna leaves in $1 \mathrm{~L}$ of $\mathrm{dH}_{2} \mathrm{O}$ for $24 \mathrm{~h}$. Then, it was diluted after being filtered with $\mathrm{dH}_{2} \mathrm{O}$. A concentration of $3 \%$ was prepared by dispersing $3 \mathrm{~mL}$ of filtered solution and $3 \mathrm{~mL}$ glycerol

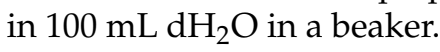

\subsection{Treatment of Guava Fruit}

A total of 600 clean complete fruits were chosen and haphazardly allocated into 5 treatments with 3 replicates (40 fruits/replicate) and expressed as control: $10 \%$ of GA; $10 \%$ of GA $+10 \%$ of moringa leaves extract; $10 \%$ of GA $+10 \%$ of cactus pear stems extract; and $10 \%$ of GA $+3 \%$ of Henna leaves extract. All guava fruits were dipped in the different 
extract solutions for $2.5 \mathrm{~min}$. Then, these fruits were dropped in 10\% GA solutions for another $2.5 \mathrm{~min}$. After dropping treatments, the fruits were allowed to dry for $60 \mathrm{~min}$ at RT by an electric fan. After that, the fruits in each treatment were wrapped in foam sheets enclosed with punched polyethylene layers with a thickness of $0.04 \mathrm{~mm}$ and then boxed in cardboard boxes with measurements of $35 \times 25 \times 10 \mathrm{~cm}$. All untried boxes were kept at $7 \pm 1{ }^{\circ} \mathrm{C}$ and $90 \pm 5 \% \mathrm{RH}$ for 24 days. the physical measurements were analyzed at harvest time and then every 7 days they had breaks from the cold-storage time.

\subsection{Determination of Fruit Physical Properties}

Fruit weight loss (\%) was estimated by the next formula:

$\frac{\text { Fruit weight before storage }- \text { fruit weight after each period of cold storage }}{\text { Fruit weight before storage }} \times 100$

Fruit decay (\%) was documented every 8 days of cold storage by calculating the number of rotten fruits owing to fungus, or any microorganism's infection, and expressed as a percentage of the original number of kept fruits using the next equation:

$$
\frac{\text { Number of decayed fruit at specific storage period }}{\text { Intial number of stored fruits }} \times 100
$$

Marketable fruit (\%) was calculated by the next formula:

$$
\frac{\text { Number of sound fruit at specific storage period }}{\text { Intial number of stored fruits }} \times 100
$$

Fruit firmness was determined in three guava fruits per replicate at two equatorials at differing sites, to measure the penetration force using a hand-held fruit firmness tester (FT327, Valencia, Italy) fortified with an $8 \mathrm{~mm}$ cylindrical stainless steel plunger tip (Watkins and Harman, 1981). Two senses were shown on each fruit flesh after peeling. The firmness value was calculated in terms of kilogram-force $\left(\mathrm{kg}_{\mathrm{f}}\right)$ and data was assessed as Newton $(\mathrm{N})$.

\subsection{Fruit Chemical Characteristics}

\subsubsection{Fruit Pigments}

Chlorophyll and carotenoid contents in the pulp of guavas (three replicates) were spectrophotometrically measured using the assay of Wellburn (1994). The absorbance of the extract was determined at a spectrum of $663 \mathrm{~nm}$ for chlorophyll a, $646 \mathrm{~nm}$ for chlorophyll b and 470 for carotene using a spectrophotometer (UV1901PC spectrophotometer). Pigment contents were calculated by the next equations:

$$
\begin{aligned}
& \text { Chlorophyll a }\left(\mu \mathrm{g} \mathrm{mL}^{-1}\right)=12.21 \text { E663 }-2.81 \text { E646 } \\
& \text { Chlorophyll b }\left(\mu \mathrm{g} \mathrm{mL}^{-1}\right)=20.13 \text { E646 }-5.03 \text { E663 }
\end{aligned}
$$

Total chlorophyll $\left(\mu \mathrm{g} \mathrm{mL}^{-1}\right)=$ Chlorophyll $\mathrm{a}+$ chlorophyll $\mathrm{b}$

Total carotenoide $\left(\mu \mathrm{g} \mathrm{mL}^{-1}\right)=[(1000$ E470 $)-(3.27 \times$ Chlorophyll a $+104 \times$ Chlorophyll b) $] / 198$

where $\mathrm{E}=$ Optical density at the specified spectrum length and findings were calculated as $\mathrm{mg} / 100 \mathrm{~g}$ of fresh weight (FW).

2.6.2. Ascorbic Acid, TSS, Titratable Acidity (TA), and TSS/TA Ratio, TPC and TAA of the Pulp

After each cold-storage period, 15 guava fruits from each treatment (3 replicates) were separated by pounding the pulp; then, the juice was drained via a muslin cloth and utilized for quantifying interior fruit quality [37], as indicated. 
For ascorbic acid analysis, sections of fruit juice were utilized, the oxalic acid solution was mixed to each sample, titrated with 2,6-dichlorophenol-indophenol dye solution, calculated as a mg of ascorbic acid, and expressed as $\mathrm{mg} / 100 \mathrm{~mL}$ of the juice.

Fruit juice TSS was quantified using a hand refractometer, 0-32 scale (ATAGO N-1E, Japan) and conveyed in Brix after making the temperature correction at $20^{\circ}$.

For juice TA, an aliquot of fruit juice was taken and titrated against $0.1 \mathrm{~N} \mathrm{NaOH}$ with phenolphthalein as a marker to the endpoint, and stated as (\%) of citric acid. revealed.

Fruit TSS/TA ratio was expressed from the values noted for fruit juice TSS and TA

Total phenolic content (TPC) and total antioxidant activity (TAA) were quantified in the $\mathrm{MeOH}$ extract $(80 \%)$ of dried guava pulp. TPC was assessed using the Folin-Ciocalteu reagent, as explained by Kähkönen et al. [38]. TAA was assessed based on the scavenging activity of the stable 1,1-diphenyl-2-picrylhydrazyl (DPPH) radical and conveyed as $\mathrm{IC}_{50}$ $(\mathrm{mg} / \mathrm{mL})$, which signified the quantity of the plant sample extract essential to decrease the early concentration of DPPH radicals by 50\% [39].

\subsubsection{Total Pectin}

Quantities of pectic substances in guava were calorimetrically quantified by the carbazole sulfuric acid, using the assay of $\mathrm{Yu}$ et al. [40]. The results were conveyed as $\mathrm{g}$ anhydro galacturonic acid (A. G. A) per 100 gm on a dry weight basis.

\subsection{Shelf-Life Period}

After 24 days of cold storage at $7 \pm 1{ }^{\circ} \mathrm{C}$, the guava (15 fruit per replicate) were obtained and arranged at ambient conditions $\left(22-24{ }^{\circ} \mathrm{C}\right.$ and $\left.65 \pm 5 \% \mathrm{RH}\right)$, till $30 \%$ of fruits became bad, or rotting happened. Then, the number of days was documented as deemed for the shelf-life period of the guava.

\subsection{Inoculation of Fruits}

Inoculation of guava was performed by squirting fruits with spore suspension $\left(10^{6}\right.$ spores $\left./ \mathrm{mL}\right)$ of $R$. stolonifer as causative agents of soft rot disease, then air-dried at RT. All were treated with each dose, and the control treatment were exemplified at 3 replicates, with 15 fruits for each replicate. All fruits were kept at $20 \pm 2{ }^{\circ} \mathrm{C}$ for 15 days and infection (\%) was noted. All the above-noted parameters were quantified in 20 fruits, and the average values were selected at the early time (Table 1).

Table 1. Characteristics of guava fruit prior to storage.

\begin{tabular}{|c|c|}
\hline Parameters & Values \\
\hline Weight loss (\%) & 0.00 \\
\hline Decay $(\%)$ & 0.00 \\
\hline Marketable (\%) & 100.00 \\
\hline Firmness (N) & 67.91 \\
\hline TSS (\%) & 7.01 \\
\hline Acidity $(\%)$ & 1.11 \\
\hline TSS/Acid ratio & 6.32 \\
\hline Ascorbic acid (mg/100 mL juice) & 105.15 \\
\hline Total chlorophyll (mg/100 g FW) & 16.15 \\
\hline Total Carotenoids (mg/100 g FW) & 5.39 \\
\hline Total sugars (\%) & 1.65 \\
\hline Total Pectin (\%) & 0.69 \\
\hline Total Phenolic ( $\left.\mathrm{IC}_{50} \mathrm{mg} / \mathrm{mL}\right)$ & 39.11 \\
\hline Antioxidants $\left(\mathrm{IC}_{50} \mathrm{mg} / \mathrm{mL}\right)$ & 210.17 \\
\hline Rhizopus Rot infection (\%) & 0.00 \\
\hline
\end{tabular}




\subsection{Statistical Analysis}

This experiment was assembled in a wholly randomized design, with 3 replicates consisting of two factors: postharvest treatments and storage period. This experiment was analyzed as a factorial experiment. Data calculated as (\%) were altered to the arcsine of the square root before statistical analysis, and non-transformed means are displayed as they were. The effects of postharvest treatments and cold-storage period on several properties were statistically analyzed by ANOVA, using the MSTAT-C statistical package. Comparisons among means were performed by Duncan's multiple range test (DMRT) at probability $\leq 0.05$.

\section{Results}

\subsection{Weight Loss (\%), Decay (\%), Rot and Marketable (\%)}

With the advance of the cold-storage period, fruit weight loss and fruit decay percentages were significantly increased, whereas marketable fruit (\%) significantly decreased (Figure 1). Weight loss increased during storage and recorded the highest values in control fruit after 21 days. Weight loss (\%) was significantly lowered in samples that were coated with GA $(10 \%)$, GA $(10 \%)+$ moringa $(10 \%)$, GA $(10 \%)+$ cactus $(10 \%)$, and GA $(10 \%)+$ henna (3\%). Moreover, the lowest values of weight loss were coupled with the treatment GA $(10 \%)+$ moringa extract $(10 \%)$, during cold-storage and both experimental seasons. Additionally, concerning decay percentage, all edible-coating treatments recorded significant reductions compared with the uncoated samples. Among all treatments, fruits that were coated with GA $(10 \%)+$ moringa $(10 \%)$ obtained the lowest values of decay percentage compared with all treatments. Furthermore, rot (\%) increased as storage days progressed, and the control treatment scored the highest values during both seasons. Alternatively, fruit samples coated with GA $(10 \%)+(10 \%)$ moringa, and GA $(10 \%)+$ henna $(10 \%)$ obtained the lowest averages in rot percentages during the 2019 and 2020 experimental seasons. On the contrary, the marketability fruit percentage significantly decreased in all treatments, as well as with increasing storage days. In this respect, the natural edible coatings kept the marketability of guava higher than uncoated fruits, and fruits samples coated with GA $(10 \%)$ and GA $(10 \%)+$ moringa $(10 \%)$ also kept the fruit at a higher percent, although there were the significant differences among treatments.
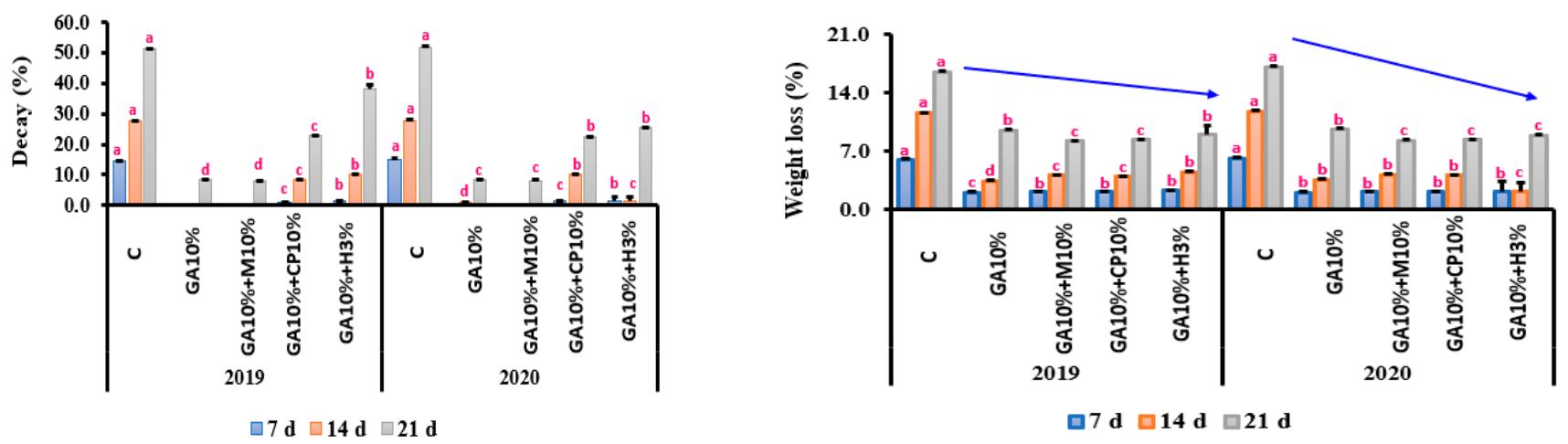

Figure 1. Cont. 

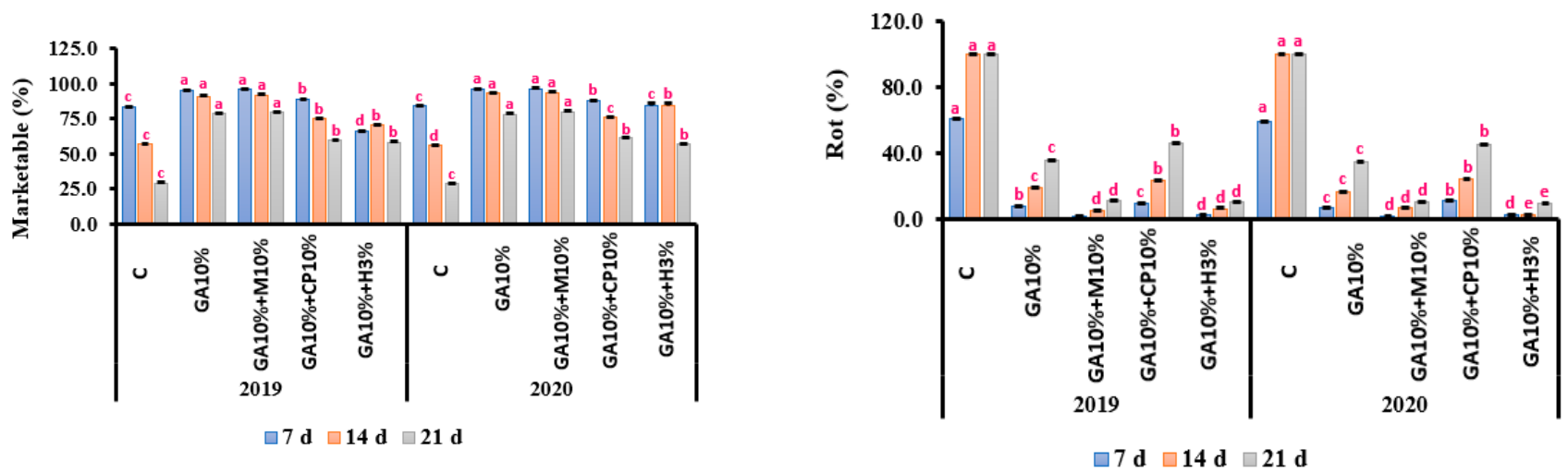

Figure 1. Effect of edible coatings of moringa extract, cactus pear, and henna, and GA, on weight loss, decay, rot, and marketable percentages of guava fruits during cold storage for 21 days throughout two seasons (2019-2020). The superscript letters, present the significantly between effect of treatments using Duncan's multiple range tests.

\subsection{Firmness (N), TSS (\%), Acidity (\%), and TSS/Acid (\%)}

Data in Figure 2 suggest there were significant differences among the treatments. Respecting firmness, the fruit samples handled with GA (10\%) and GA (10\%) + moringa $(10 \%)$ appeared to have higher values of firmness during storage periods, as well as during both experimental seasons, compared with the other coated and uncoated treatments which recorded the lowest firmness values. Moreover, there were notable decreases in firmness when storage days were increased.
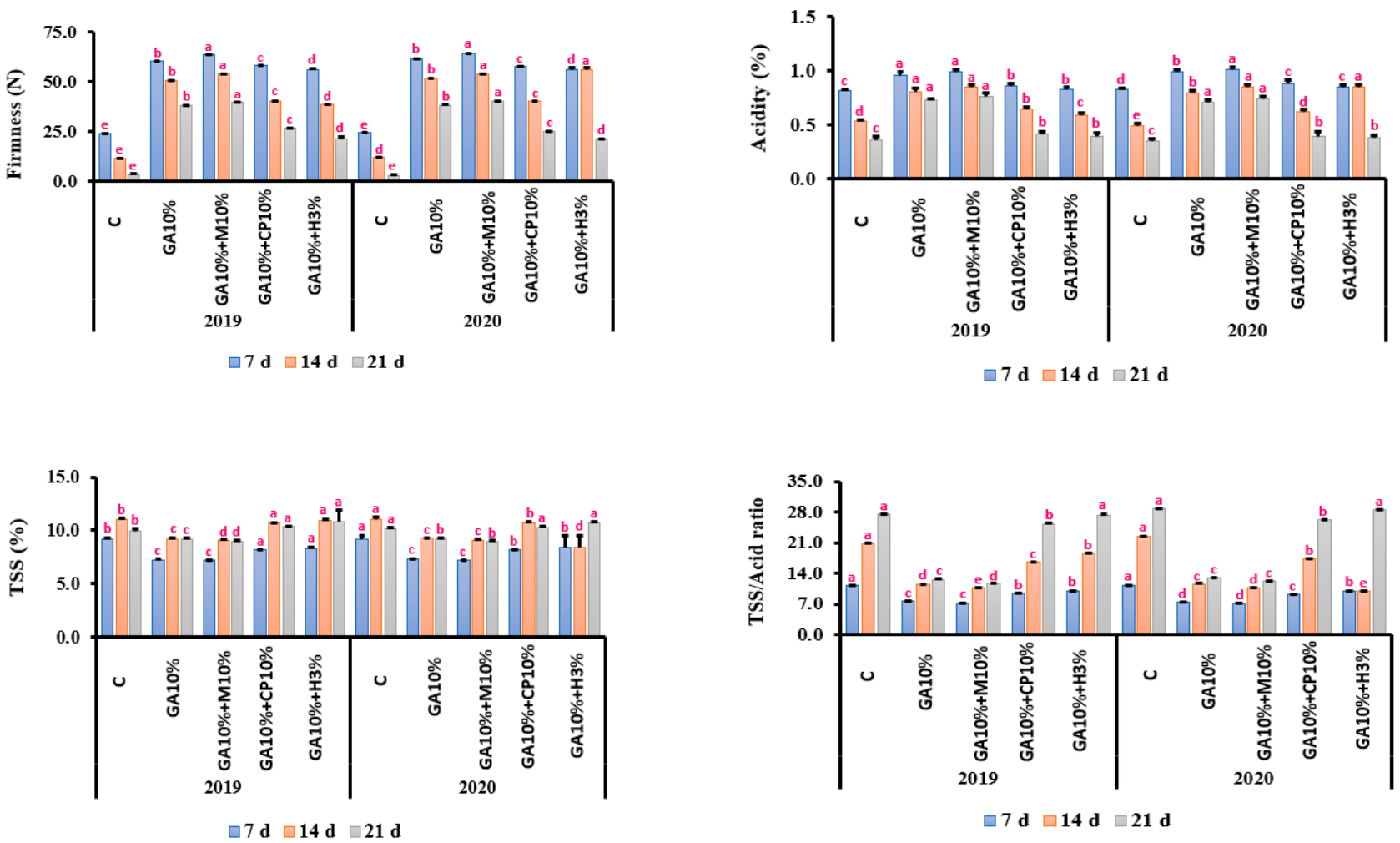

Figure 2. Effect of edible coatings moringa extract, cactus pear, henna and GA, on firmness (N), TSS (\%), acidity (\%), and TSS/acid ratio of guava during cold storage for 21 days throughout two seasons (2019-2020). The superscript letters, present the significantly between effect of treatments using Duncan's multiple range tests. 
As for both TSS and TSS/acid ratio, the studied treatments showed the differences among them in this respect, but there was no specific direction in these traits during both seasons. Concerning acidity, the data indicated that there were significant differences among treatments during storability days as well as during both seasons. From these data, the highest values of acidity were obtained with GA $(10 \%)$ and GA $(10 \%)+$ moringa $(10 \%)$ in the 2019 and 2020 seasons.

\subsection{Total Sugars and Pectin}

Respecting the effects of used edible coatings on total sugars and total pectin (\%), Figure 3 shows the differences among the studied treatments. Control treatments (uncoated samples) were coupled with the highest total sugar percentage followed by GA (10\%) + henna $(3 \%)$, and the other treatments showed intermediate values. As for total pectin (\%), Figure 3 shows the opposite effect than total sugar content. In this regard, fruit samples coated with GA $(10 \%)$ and GA $(10 \%)+$ moringa $(10 \%)$ scored the higher averages of pectin content than the others. There were gradual increases in pectin content in contents of storage days from 7 to 21 days in both treatments and both seasons.
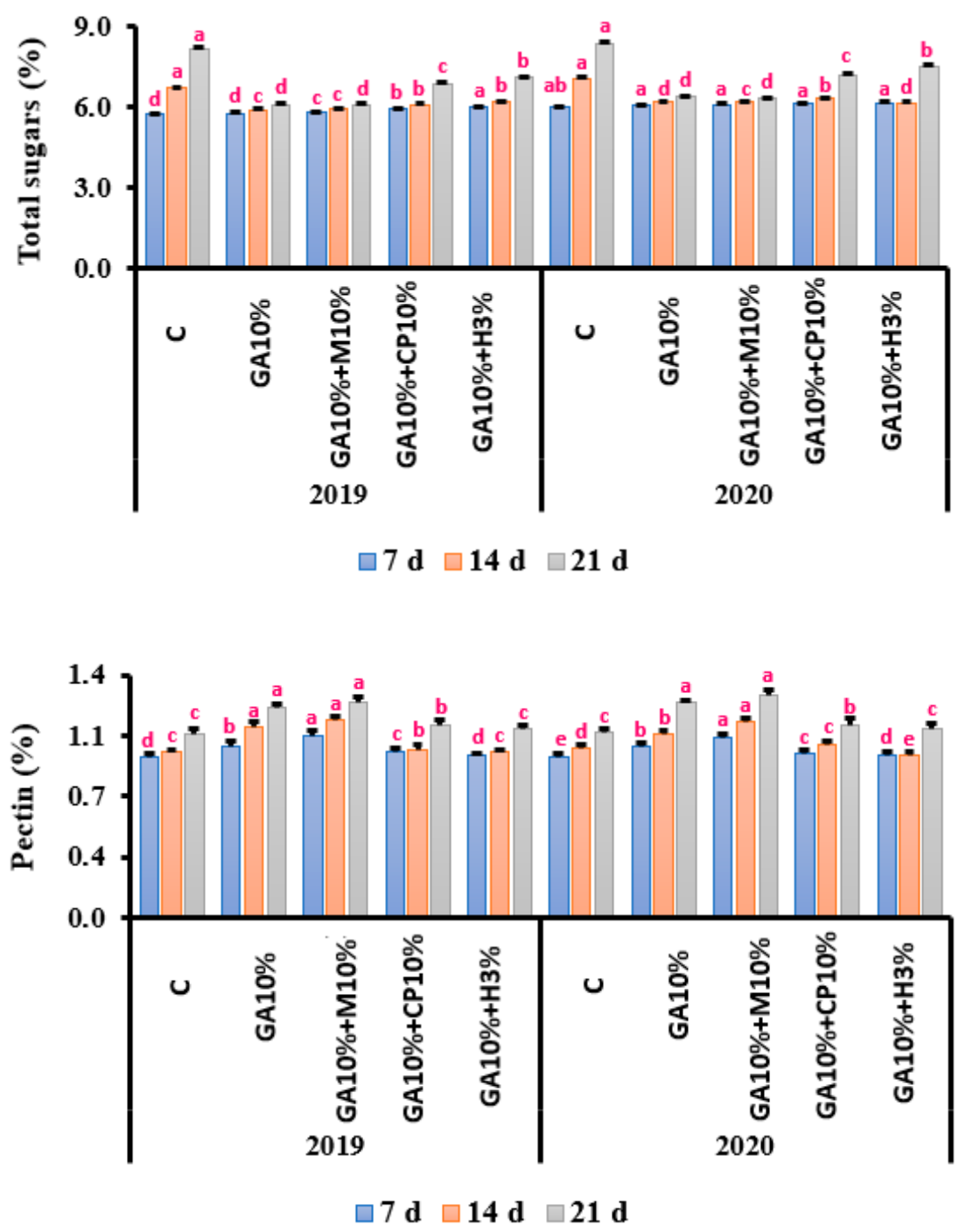

Figure 3. Effect of edible coatings-moringa extract, cactus pear, henna, and GA-on total sugars and pectin (\%) of guava during cold storage for 21 days throughout two seasons (2019-2020). The superscript letters, present the significantly between effect of treatments using Duncan's multiple range tests. 


\subsection{Effects on Total Carotenoid and Total Chlorophyll}

Figure 4 shows the effects of edible coatings based on GA on the total carotenoid and total chlorophyll contents of the treated guava fruits. Regarding total carotin, we noticed that for the exception of the control treatment (uncoated fruits) the carotin values were in the lower content on the 7th day, which increased on the 14th day, and then decreased on day 21. The uncoated fruits' carotin content gradually decreased during the storage periods. Concerning the chlorophyll content, all edible-coating treatments were kept in higher averages than uncoated fruits. GA $(10 \%)$ and GA $(10 \%)+$ moringa $(10 \%)$ recorded the higher values compared with the others.
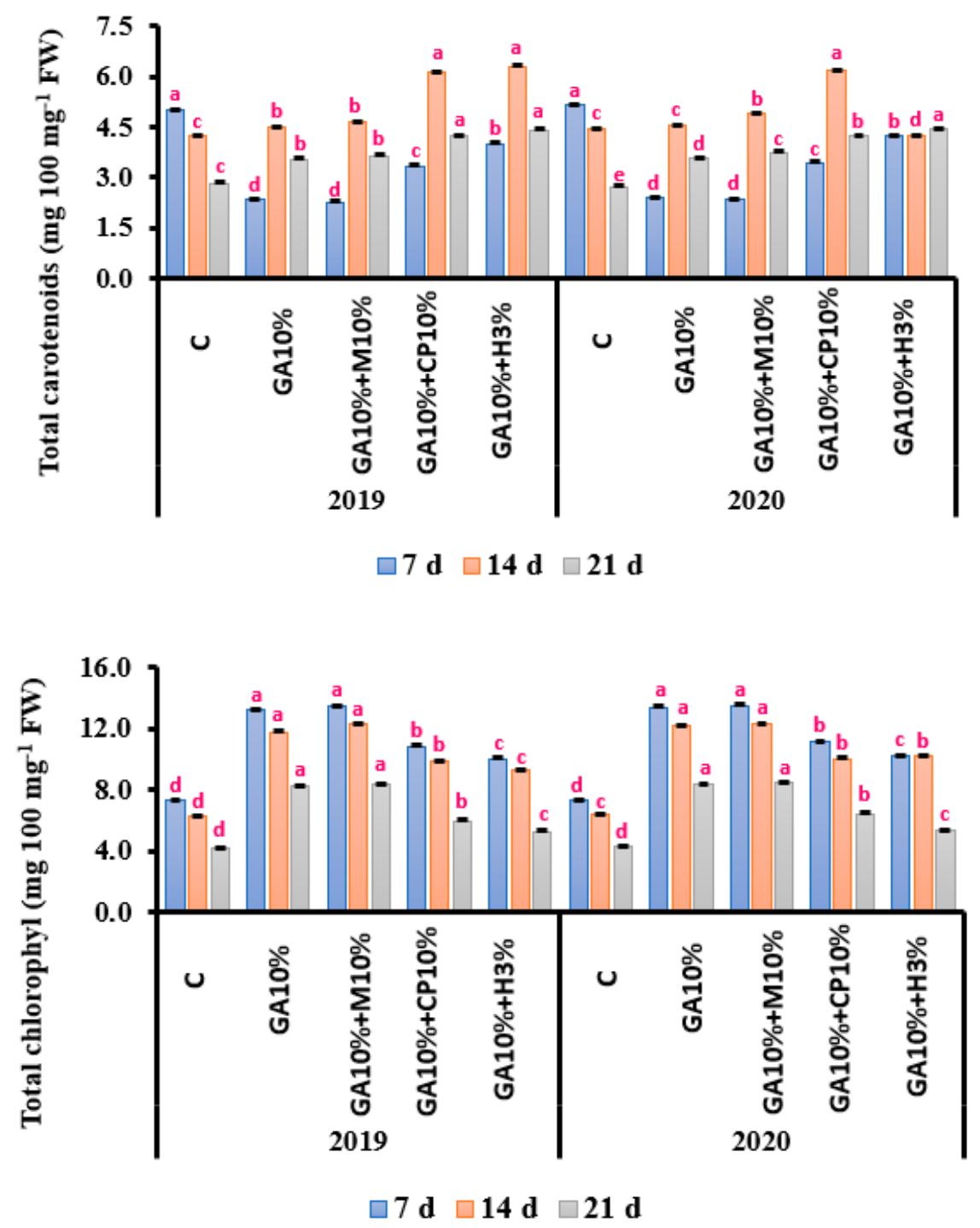

Figure 4. Effect of edible coatings-moringa extract, cactus pear, henna, and GA—on total carotenoid and total chlorophyll (mg $100 \mathrm{mg}^{-1} \mathrm{FW}$ ) of guava during cold storage for 21 days throughout two seasons (2019-2020). The superscript letters, present the significantly between effect of treatments using Duncan's multiple range tests.

\subsection{Effects on VC Juice Content, Total Phenols, and Antioxidants Activity}

With respect to VC content (Figure 5), all edible coatings treatments were kept it in higher averages compared with the uncoated fruits, and GA $(10 \%)$ and GA $(10 \%)+$ moringa $(10 \%)$ recorded the higher values compared with the others. Regarding the total phenol content, there were slight significant differences among all treatments (Figure 5). From these data, control treatment of uncoated samples recorded higher values compared with 
the other treatments, in both 2019 and 2020 seasons. Meanwhile, the treatments GA (10\%) and GA $(10 \%)+$ moringa $(10 \%)$ reduced total phenol contents, compared with all treated and untreated samples during the two experimental seasons. Moreover, the total phenol contents were in the lower content at the 7th day, which increased at the 14th day, and then decreased on day 21. For all treatments during 2019 and 2020 seasons, this carotenoid trend was exhibited. As for antioxidant activity, the control exhibited bigger averages than all treatments. The opposite trend also appeared for total carotenoids during storage days; there was higher content at the 7th day, which decreased on the 14th day, and then increased at day 21 in both treatments during the two studied seasons.
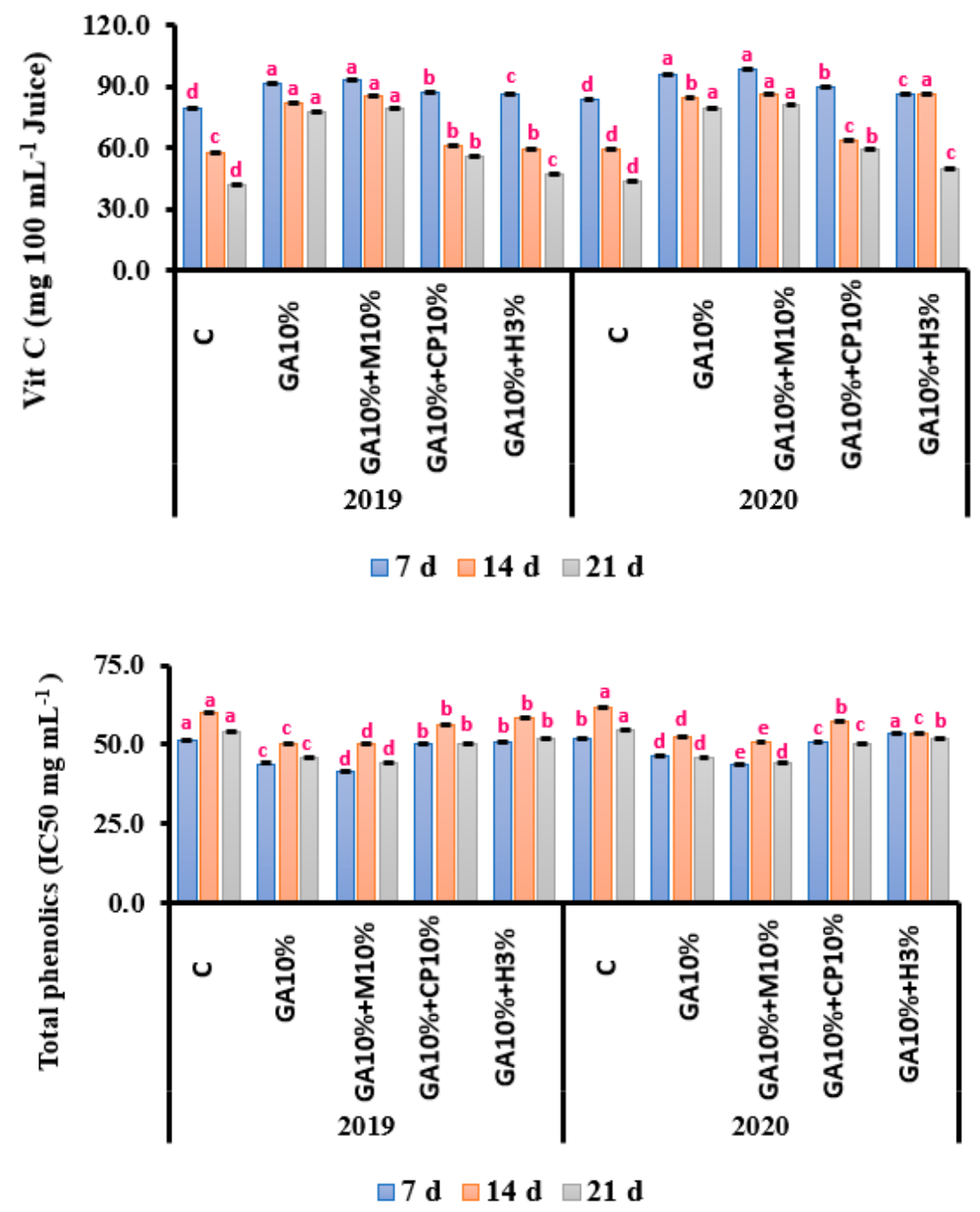

Figure 5. Cont. 


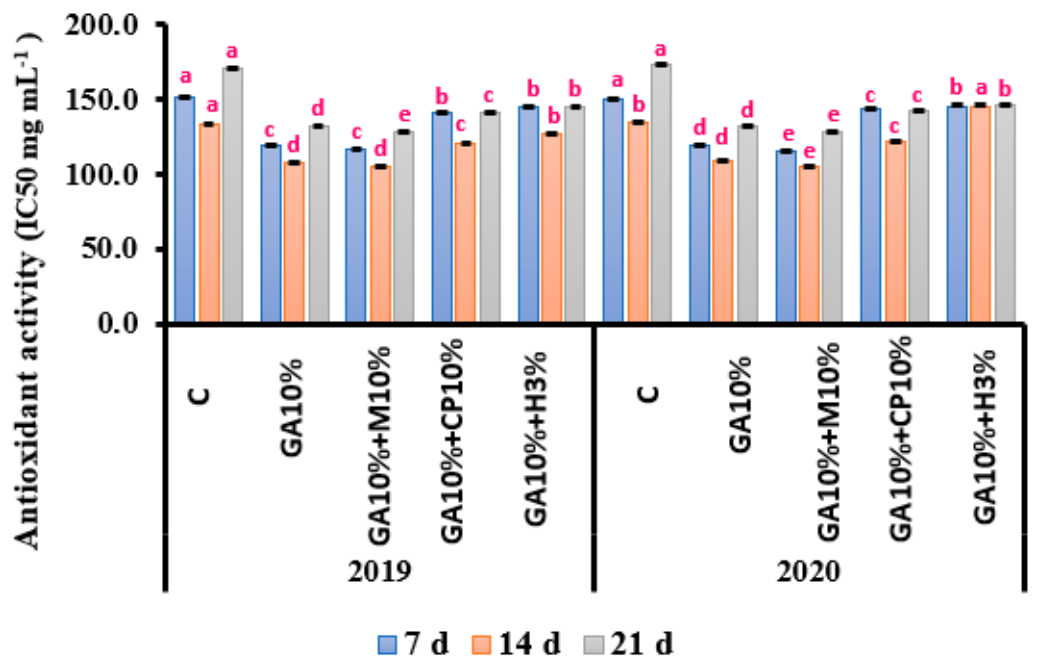

Figure 5. Effect of edible coatings-moringa extract, cactus pear, henna, and GA — on VC juice content, total phenols, carotenoid, and antioxidants activity $\left(\mathrm{IC}_{50} \mathrm{mg} 100 \mathrm{mg}^{-1} \mathrm{FW}\right.$ ) of guava during cold storage for 21 days throughout two seasons (2019-2020). The superscript letters, present the significantly between effect of treatments using Duncan's multiple range tests.

\subsection{Effects on the Shelf Life}

Data revealed that, all treatments enhanced the shelf-life periods of guava fruit coated with the natural edible materials over the control, and the superior treatments in this respect were GA (10\%) and GA (10\%) + moringa leaf extract $(10 \%)$ during two studied seasons, 2019 and 2020, respectively (Figure 6).

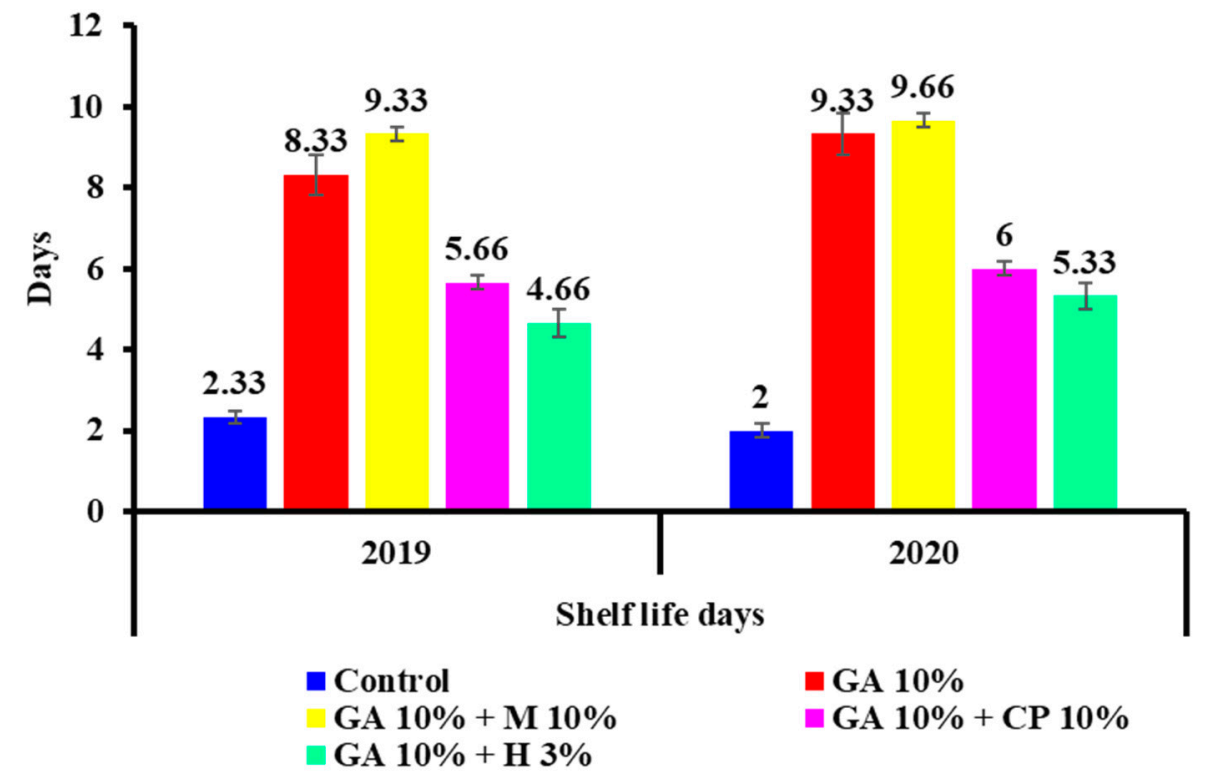

Figure 6. Effect of edible coatings—moringa extract, cactus pear, henna and GA—on shelf life of guava during cold storage.

\subsection{Relationship among Fruit Characteristics}

Correlation analysis was applied for investigating the interdependence of the guava characteristics (Figure 7). The results indicated that weight loss, decay, TSS, TSS/acid, total sugar, antioxidant, and rot had a negative relationship to firmness. This strong relationship revealed that greater guava had lesser antioxidant activity, which agrees with the resulted relationship for blackberries [41,42]. Strong positive correlations were found between firmness and acidity, V.C, and total chlorophyl. The marketable percentage was positively 
linked to firmness, acidity, V.C. and total chlorophyl; thus, these indicators could be used to forecast other results. Meanwhile, marketable percentage was negatively correlated with weight loss, decay, TSS, TSS/acid, total sugar, antioxidant, and rot, verifying that some physicochemical changes could cause lower acceptance by the consumers, and consequently create lesser marketability. PCA was utilized to discover the connection among the variables. Thus, PCA was utilized to discover the relationships among parameters in different treatments. PCA analysis revealed that the first principal component $\left(\mathrm{PC}_{1}\right)$ and the second principal component $\left(\mathrm{PC}_{2}\right)$ were 82.5 and $17.5 \%$, respectively, with the accumulative variance contribution rate of $99 \%(>75-85 \%) . P_{1}$ was positively associated with the variables: VC, pectin, acidity, sugars, antioxidants, weight loss, firm, and decay area. $\mathrm{PC}_{2}$ was positively associated with the variables of TSS, phenolics, carotene, and chlorophyl. Furthermore, locations of the combined GA with natural extracts and the functional and freshness properties were close, showing the impact of GA-natural extracts on the quality of guava during the cold storage.

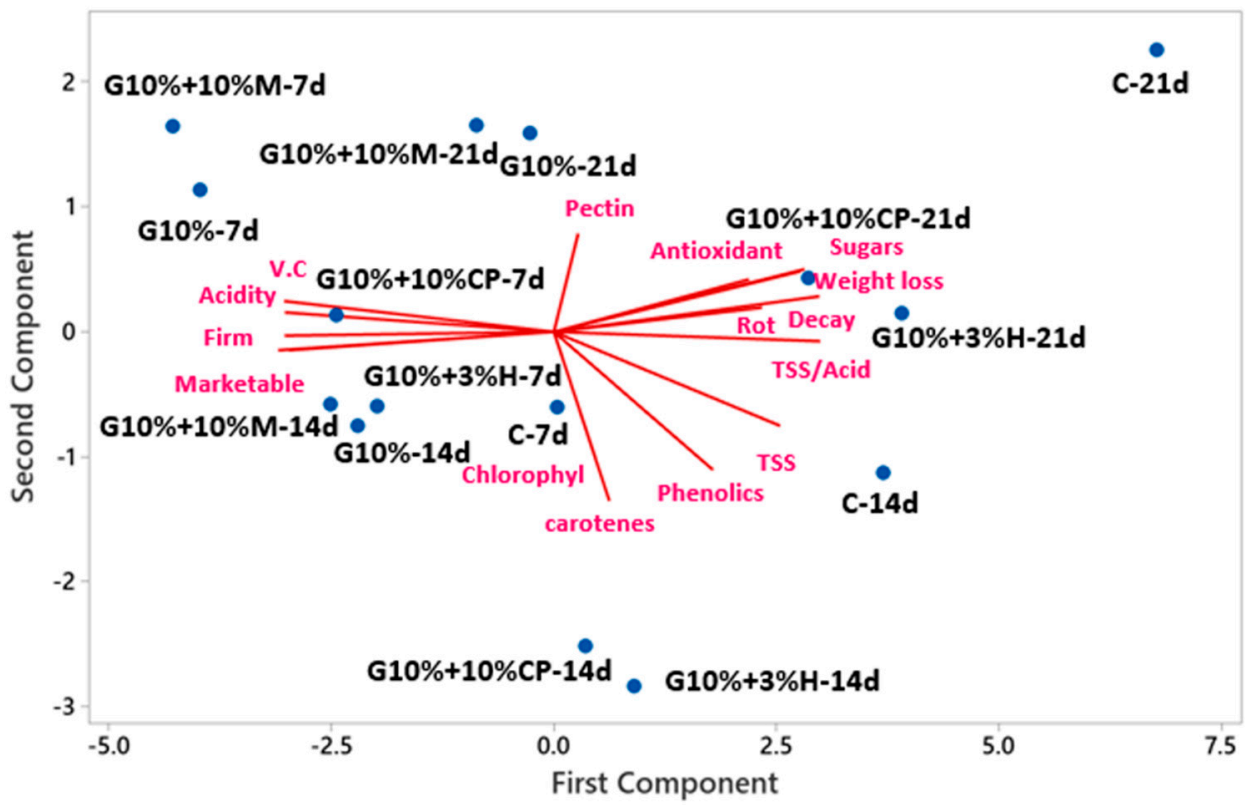

Figure 7. PCA analysis of the different treatments with different parameters.

\section{Discussion}

Edible coatings have barrier features that decrease a fruits' surface permeability to oxygen and carbon dioxide, resulting in a change in internal gas composition that reduces oxidative metabolism and increases the fruit's shelf life [43]. We proposed that coating fruits with GA would result in significant differences, and increase the fruit shelf-life [20,44].

Water exchange between the interior and exterior atmospheres is believed to be the primary cause of fruit weight loss and decay percentage, resulting in a low marketable percentage during cold storage. With the advancement of cold storage, the growth in transpiration ratio, ethylene making, and the cellular interruption of fruits resulted in a rise in the physiological failure of weight and decay prevalence, and a reduction in saleable guavas [45-47].

Consequently, the use of GA can decrease the gases exchange among orange fruits and the environment by accumulating carbon dioxide in fruits with low $\mathrm{O}_{2}$-availability for respiration and, as a result, inhibit respiratory enzymes. Furthermore, GA coating can close openings in the peel. Furthermore, the coating can impede the fungi growth in a wide range of horticultural products [48]. This application improved membrane integrity, postponed fruit senescence, and reduced transpiration and respiration [49]. However, coating alters the atmosphere and inhibits the gaseous exchange of the fruit, which prevents ascorbic acid oxidation by limiting the entry of oxygen into the fruit's interior [50]. The lower TSS values 
in treated samples compared with the controls could be attributed to the conversion of organic acids to sugars via gluconeogenesis and the solubilization of cell wall ingredients by galactosidases and glucosidases found in guava fruit [51].

These findings are matched with those obtained by [25]; they indicate that guava fruits coated with $10 \%$ GA showed a significant reduction in weight loss (\%) and a delay in the change in firmness, titratable acidity, soluble solid concentration color, maintaining the sensory quality during storage at room temperature, as compared with the uncoated control fruit of banana and papaya fruits, as well as Khaliq, Mohamed, Ali, Ding and Ghazali [23] in 'Choke Anan' mangoes, who reported that treated fruits with edible GA coatings had significantly higher firmness than uncoated fruits during cold storage. Moreover, in avocado fruit (Maluma), the application of GA at 10 or 15\% + Moringa leaf extracts maintained higher firmness than other treatments [33]. A similar effect was found in mass loss, with fruit covered with the previously stated coatings showing minimal change. It may be argued that the prevention of moisture loss was the primary reason why coated fruit remained firmer than uncoated fruit. This theory is supported by [29], who found that moisture loss is not only associated with mass loss, but also fruit softening.

Cactus pear extracts and henna leaf extracts significantly decreased weight loss, compared with the control, during cold storage in both seasons. The antimicrobial and antifungal properties of henna leaf extract, as well as its antioxidant activity, contribute to its promising effect in delaying fruit weight loss and decay percentage. In addition, prickly pear has antimicrobial and antioxidant properties.

Lawsone makes up about 0.5 to 1.5 percent of the ingredients in henna. The main constituent responsible for the plant's dyeing properties is lawsone (2-dihydroxynaphthoquinone). Henna, on the other hand, contains mannitol, tannic acid, mucilage, and gallic acid. These substances are present in henna as a mixture. The antimicrobial activity could be attributed to many free hydroxyls that can combine with carbohydrates and proteins in the bacterial cell wall. They may become entangled with enzyme sites, proformance them inactive [52]. When compared with alcoholic and oily extracts, water extracts had no antibacterial activity. This could be due to a lack of solvent properties, which are key in antibacterial effectiveness.

Phenolic compounds are antioxidants that act as protective mechanisms in fruit. TPC content has a defense mechanism against plant pathogen invasion and plays an important role in plant resistance $[2,53]$. Furthermore, trapping the lipid alkoxyl radicals, antioxidants and phenols could significantly reduce reactive oxygen species (ROS) and prevent lipid peroxidation in plant tissue $[2,54,55]$. Maintaining TPC and increasing TAA could be attributed to postharvest treatments' ability to scavenge excess ROS and, as a result, reduce oxidative damage to the fruits $[23,56,57]$.

Hence, the use of GA can reduce gas exchange among orange fruits and the environment by accumulating carbon dioxide in the fruits, resulting in low availability of $\mathrm{O}_{2}$ for respiration and, as a result, the reticence of respiratory enzymes. Furthermore, GA-coating can plug openings in the peel. Furthermore, a coating can prevent the growth of fungi in a variety of horticultural products [48].

\section{Conclusions}

Overall, our findings indicated that both postharvest applications "cactus pear stem $(10 \%)$, moringa $(10 \%)$, and henna leaf $(3 \%)$ extracts incorporated with gum Arabic $(10 \%)$ " and their combinations had a positive impact on the quality characteristics of 'Maamoura' guavas during cold storage. The combined treatments of $10 \% \mathrm{GA}+10 \%$ moringa leaf extract were the most effective coating for fresh guava after long periods of cold storage. These applications significantly reduced weight loss, decay and Rhizopus rot infection $(\%)$, while also increasing marketable percentage, and delaying fruit softening during cold storage. Furthermore, these applications delayed color development by significantly retaining total chlorophyll content, maintaining fruit content in vitamin $\mathrm{C}$ and acidity, and slowing the accumulation of fruit contents in TSS and TSS/acid ratios compared with untreated fruits during the cold-storage period. Finally, compared with the control, these 
applications significantly increased the shelf-life period at ambient conditions after the end of the cold-storage period.

Author Contributions: Conceptualization, M.F.M.A., M.S.G., A.M.E.B. and L.A.A.; methodology, M.F., A.R.M., M.H.M., H.M.A.E.G. and A.M.R.A.A.; software, H.M.A.E.G. and K.H.A.H.; validation, S.F.E.-G., M.S.G., A.M.E.B. and M.H.M. formal analysis, S.F.E.-G.; investigation, M.H.M. and H.M.A.E.G.; data curation, K.H.A.H.; writing—original draft preparation, S.F.E.-G., M.S.G., A.M.E.B., M.F.M.A. and K.H.A.H.; writing-review and editing, S.F.E.-G., M.S.G., A.M.E.B., M.F.M.A., M.F., A.R.M., A.M.R.A.A. and H.A.S.A.; funding acquisition, M.F.M.A., M.A.A., D.M.H. and L.A.A. All authors have read and agreed to the published version of the manuscript.

Funding: The authors extend their appreciation to King Saud University for supporting this work. Researchers Supporting Project under project number (RSP-2021/406), King Saud University, Riyadh, Saudi Arabia.

Institutional Review Board Statement: Not applicable.

Informed Consent Statement: Not applicable.

Data Availability Statement: Relevant data applicable to this research are within the paper.

Conflicts of Interest: The authors declare no conflict of interest.

\section{References}

1. Valencia-Chamorro, S.A.; Palou, L.; Del Río, M.A.; Pérez-Gago, M.B. Antimicrobial edible films and coatings for fresh and minimally processed fruits and vegetables: A review. Crit. Rev. Food Sci. Nutr. 2011, 51, 872-900. [CrossRef] [PubMed]

2. Lo'ay, A.A.; Doaa, M.H. The potential of vine rootstocks impacts on 'Flame Seedless' bunches behavior under cold storage and antioxidant enzyme activity performance. Sci. Hortic. 2020, 260, 108844. [CrossRef]

3. Lo'ay, A.A.; El-Khateeb, A.Y. Impact of chitosan/PVA with salicylic acid, cell wall degrading enzyme activities and berries shattering of 'Thompson seedless' grape vines during shelf life. Sci. Hortic. 2018, 238, 281-287. [CrossRef]

4. Kocira, A.; Kozłowicz, K.; Panasiewicz, K.; Staniak, M.; Szpunar-Krok, E.; Hortyńska, P. Polysaccharides as Edible Films and Coatings: Characteristics and Influence on Fruit and Vegetable Quality-A Review. Agronomy 2021, 11, 813. [CrossRef]

5. Murmu, S.B.; Mishra, H.N. Optimization of the arabic gum based edible coating formulations with sodium caseinate and tulsi extract for guava. LWT 2017, 80, 271-279. [CrossRef]

6. Lo'ay, A.A.; Dawood, H.D. Minimize browning incidence of banana by postharvest active chitosan/PVA Combines with oxalic acid treatment to during shelf-life. Sci. Hortic. 2017, 226, 208-215. [CrossRef]

7. Mahajan, P.V.; Oliveira, F.; Macedo, I. Effect of temperature and humidity on the transpiration rate of the whole mushrooms. J. Food Eng. 2008, 84, 281-288. [CrossRef]

8. Forato, L.A.; de Britto, D.; de Rizzo, J.S.; Gastaldi, T.A.; Assis, O.B. Effect of cashew gum-carboxymethylcellulose edible coatings in extending the shelf-life of fresh and cut guavas. Food Packag. Shelf Life 2015, 5, 68-74. [CrossRef]

9. Lo'ay, A.A.; Dawood, H.D. Active chitosan/PVA with ascorbic acid and berry quality of 'Superior seedless' grapes. Sci. Hortic. 2017, 224, 286-292. [CrossRef]

10. Yan, J.; Luo, Z.; Ban, Z.; Lu, H.; Li, D.; Yang, D.; Aghdam, M.S.; Li, L. The effect of the layer-by-layer (LBL) edible coating on strawberry quality and metabolites during storage. Posthavest Biol. Technol. 2019, 147, 29-38. [CrossRef]

11. Klangmuang, P.; Sothornvit, R. Active coating from hydroxypropyl methylcellulose-based nanocomposite incorporated with Thai essential oils on mango (cv. Namdokmai Sithong). Food Biosci. 2018, 23, 9-15. [CrossRef]

12. Perdones, A.; Sánchez-González, L.; Chiralt, A.; Vargas, M. Effect of chitosan-lemon essential oil coatings on storage-keeping quality of strawberry. Postharvest Biol. Technol. 2012, 70, 32-41. [CrossRef]

13. Saberi, B.; Golding, J.B.; Marques, J.R.; Pristijono, P.; Chockchaisawasdee, S.; Scarlett, C.J.; Stathopoulos, C.E. Application of biocomposite edible coatings based on pea starch and guar gum on quality, storability and shelf life of 'Valencia' oranges. Postharvest Biol. Technol. 2018, 137, 9-20. [CrossRef]

14. Thakur, R.; Pristijono, P.; Golding, J.; Stathopoulos, C.E.; Scarlett, C.; Bowyer, M.; Singh, S.; Vuong, Q. Development and application of rice starch based edible coating to improve the postharvest storage potential and quality of plum fruit (Prunus salicina). Sci. Hortic. 2018, 237, 59-66. [CrossRef]

15. Chen, H.; Sun, Z.; Yang, H. Effect of carnauba wax-based coating containing glycerol monolaurate on the quality maintenance and shelf-life of Indian jujube (Zizyphus mauritiana Lamk.) fruit during storage. Sci. Hortic. 2019, 244, 157-164. [CrossRef]

16. Nair, M.S.; Saxena, A.; Kaur, C. Effect of chitosan and alginate based coatings enriched with pomegranate peel extract to extend the postharvest quality of guava (Psidium guajava L.). Food Chem. 2018, 240, 245-252. [CrossRef]

17. Prakash, A.; Joseph, M.; Mangino, M. The effects of added proteins on the functionality of gum arabic in soft drink emulsion systems. Food Hydrocoll. 1990, 4, 177-184. [CrossRef] 
18. Motlagh, S.; Ravines, P.; Karamallah, K.; Ma, Q. The analysis of Acacia gums using electrophoresis. Food Hydrocoll. 2006, 20, 848-854. [CrossRef]

19. Anderson, D.; Eastwood, M. The safety of gum arabic as a food additive and its energy value as an ingredient: A brief review. J. Hum. Nutr. Diet. 1989, 2, 137-144. [CrossRef]

20. Maqbool, M.; Ali, A.; Alderson, P.G.; Zahid, N.; Siddiqui, Y. Effect of a novel edible composite coating based on gum arabic and chitosan on biochemical and physiological responses of banana fruits during cold storage. J. Agric. Food Chem. 2011, 59, 5474-5482. [CrossRef]

21. Ali, A.; Maqbool, M.; Alderson, P.G.; Zahid, N. Effect of gum arabic as an edible coating on antioxidant capacity of tomato (Solanum lycopersicum L.) fruit during storage. Postharvest Biol. Technol. 2013, 76, 119-124. [CrossRef]

22. Addai, Z.R.; Abdullah, A.; Mutalib, S.; Musa, K. Effect of gum Arabic on quality and antioxidant properties of papaya fruit during cold storage. Int. J. ChemTech Res. 2013, 5, 2854-2862.

23. Khaliq, G.; Mohamed, M.T.M.; Ali, A.; Ding, P.; Ghazali, H.M. Effect of gum arabic coating combined with calcium chloride on physico-chemical and qualitative properties of mango (Mangifera indica L.) fruit during low temperature storage. Sci. Hortic. 2015, 190, 187-194. [CrossRef]

24. Ullah, A.; Abbasi, N.; Shafique, M.; Qureshi, A. Influence of edible coatings on biochemical fruit quality and storage life of bell pepper cv. "Yolo Wonder". J. Food Qual. 2017, 2017. [CrossRef]

25. Anjum, M.A.; Akram, H.; Zaidi, M.; Ali, S. Effect of gum arabic and Aloe vera gel based edible coatings in combination with plant extracts on postharvest quality and storability of 'Gola' guava fruits. Sci. Hrotic. 2020, 271, 109506. [CrossRef]

26. Moyo, B.; Masika, P.J.; Muchenje, V. Antimicrobial activities of Moringa oleifera Lam leaf extracts. Afr. J. Biotechnol. 2012, 11, 2797-2802. [CrossRef]

27. Tesfay, S.; Modi, A.; Mohammed, F. The effect of temperature in moringa seed phytochemical compounds and carbohydrate mobilization. S. Afr. J. Bot. 2016, 102, 190-196. [CrossRef]

28. Tesfay, S.Z.; Magwaza, L.S. Evaluating the efficacy of moringa leaf extract, chitosan and carboxymethyl cellulose as edible coatings for enhancing quality and extending postharvest life of avocado (Persea americana Mill.) fruit. Food Packag. Shelf Life 2017, 11, 40-48. [CrossRef]

29. Adetunji, C.; Fawole, O.; Arowora, K.; Nwaubani, S.; Ajayi, E.; Oloke, J.; Majolagbe, O.; Ogundele, B.; Aina, J.; Adetunji, J. Quality and safety of Citrus Sinensis coated with Hydroxypropylmethylcellulose edible coatings containing Moringa oleifera extract stored at ambient temperature. Glob. J. Sci. Front. Res 2012, 12, 6.

30. Ncama, K.; Magwaza, L.S.; Mditshwa, A.; Tesfay, S.Z. Plant-based edible coatings for managing postharvest quality of fresh horticultural produce: A review. Food Packag. Shelf Life 2018, 16, 157-167. [CrossRef]

31. Yousef, A.; El-Moniem, E.; Saleh, M. The effect of some natural products on storability and fruit properties of Fuerte avocado. Int. J. ChemTech Res. 2015, 8, 1454-1462.

32. Salehi, F. Edible Coating of Fruits and Vegetables Using Natural Gums: A Review. Int. J. Fruit Sci. 2020, 20, S570-S589. [CrossRef]

33. Kubheka, S.F.; Tesfay, S.Z.; Mditshwa, A.; Magwaza, L.S. Evaluating the Efficacy of Edible Coatings Incorporated with Moringa Leaf Extract on Postharvest of 'Maluma' Avocado Fruit Quality and Its Biofungicidal Effect. HortScience 2020, 55, 410-415. [CrossRef]

34. Zegbe, J.A.; Mena-Covarrubias, J.; Domínguez-Canales, V.S.I. Cactus mucilage as a coating film to enhance shelf life of unprocessed guavas (Psidium guajava L.). Acta Hortic. 2015, 1067, 423-427. [CrossRef]

35. Habbal, O.; Hasson, S.S.; El-Hag, A.H.; Al-Mahrooqi, Z.; Al-Hashmi, N.; Al-Bimani, Z.; Al-Balushi, M.S.; Al-Jabri, A.A. Antibacterial activity of Lawsonia inermis Linn (Henna) against Pseudomonas aeruginosa. Asian Pac. J. Trop Biomed. 2011, 1, 173-176. [CrossRef]

36. Mercado-Silva, E.; Benito-Bautista, P.; de los Angeles García-Velasco, M. Fruit development, harvest index and ripening changes of guavas produced in central Mexico. Postharvest Biol. Technol. 1998, 13, 143-150. [CrossRef]

37. A.O.A.C. Official Methods of Analysis; Association of Official Analytical Chemists Washington: Washington, DC, USA, 2005.

38. Kähkönen, M.P.; Hopia, A.I.; Vuorela, H.J.; Rauha, J.-P.; Pihlaja, K.; Kujala, T.S.; Heinonen, M. Antioxidant activity of plant extracts containing phenolic compounds. J. Agric. Food Chem. 1999, 47, 3954-3962. [CrossRef]

39. Abe, N.; Murata, T.; HIRoTA, A. Novel DPPH radical scavengers, bisorbicillinol and demethyltrichodimerol, from a fungus. Biosci. Biotechnol. Biochem. 1998, 62, 661-666. [CrossRef]

40. Yu, L.; Reitmeier, C.; Love, M. Strawberry texture and pectin content as affected by electron beam irradiation. J. Food Sci. 1996, 61, 844-846. [CrossRef]

41. Wu, R.; Frei, B.; Kennedy, J.A.; Zhao, Y. Effects of refrigerated storage and processing technologies on the bioactive compounds and antioxidant capacities of 'Marion' and 'Evergreen' blackberries. LWT-Food Sci. Technol. 2010, 43, 1253-1264. [CrossRef]

42. Milosevic, T.; Mratinic, E.; Milosevic, N.; Glisic, I.; Mladenovic, J. Segregation of blackberry cultivars based on the fruit physicochemical attributes. J. Agric. Sci. 2012, 18, 100-109.

43. Dhall, R. Advances in edible coatings for fresh fruits and vegetables: A review. Crit. Rev. Food Sci. Nutr. 2013, 53, 435-450. [CrossRef]

44. Ali, A.; Maqbool, M.; Ramachandran, S.; Alderson, P.G. Gum arabic as a novel edible coating for enhancing shelf-life and improving postharvest quality of tomato (Solanum lycopersicum L.) fruit. Postharvest Biol. Technol. 2010, 58, 42-47. [CrossRef] 
45. Barman, K.; Asrey, R.; Pal, R. Putrescine and carnauba wax pretreatments alleviate chilling injury, enhance shelf life and preserve pomegranate fruit quality during cold storage. Sci. Hortic. 2011, 130, 795-800. [CrossRef]

46. El-Khalek, A.; Fathy, A. Effectiveness of gum arabic, potassium salts and their incorporation in the control of postharvest diseases and maintaining quality of 'Washington' navel oranges during long term cold storage. Egypt. J. Hortic. 2018, 45, 185-203. [CrossRef]

47. Razzaq, K.; Khan, A.S.; Malik, A.U.; Shahid, M.; Ullah, S. Role of putrescine in regulating fruit softening and antioxidative enzyme systems in 'Samar Bahisht Chaunsa' mango. Postharvest Biol. Technol. 2014, 96, 23-32. [CrossRef]

48. Tripathi, P.; Dubey, N. Exploitation of natural products as an alternative strategy to control postharvest fungal rotting of fruit and vegetables. Postharvest Biol. Technol. 2004, 32, 235-245. [CrossRef]

49. Lester, G.E.; Grusak, M.A. Field application of chelated calcium: Postharvest effects on cantaloupe and honeydew fruit quality. HortTechnology 2004, 14, 29-38. [CrossRef]

50. Baldwin, E.; Burns, J.; Kazokas, W.; Brecht, J.; Hagenmaier, R.; Bender, R.; Pesis, E. Effect of two edible coatings with different permeability characteristics on mango (Mangifera indica L.) ripening during storage. Postharvest Biol. Technol. 1999, 17, 215-226. [CrossRef]

51. Echeverria, E.; Ismail, M. Changes in sugars and acids of citrus fruits during storage. In Proceedings of the Annual Meeting of the Florida State Horticulture Society, Florida, FA, USA; 1988; pp. 50-52.

52. El-Banna, M.F.; Lo'ay, A.A. Evaluation berries shattering phenomena of 'Flame seedless' vines grafted on different rootstocks during shelf life. Sci. Hortic. 2019, 246, 51-56. [CrossRef]

53. Beckman, C.H. Phenolic-storing cells: Keys to programmed cell death and periderm formation in wilt disease resistance and in general defence responses in plants? Physiol. Mol. Plant Pathol. 2000, 57, 101-110. [CrossRef]

54. Blokhina, O.; Virolainen, E.; Fagerstedt, K.V. Antioxidants, oxidative damage and oxygen deprivation stress: A review. Ann. Bot. 2003, 91, 179-194. [CrossRef] [PubMed]

55. Lo'ay, A.A.; Ameer, N.M. Performance of calcium nanoparticles blending with ascorbic acid and alleviation internal browning of 'Hindi Be-Sennara' mango fruit at a low temperature. Sci. Hortic. 2019, 254, 199-207. [CrossRef]

56. Devi, R. Role of Gibberellic Acid and Calcium Chloride in Ripening Related Biochemical Changes in Guava (Psidium guajava L.) Fruit. Ph.D. Thesis, CCSHAU, Hisar, India, 2016.

57. Lo'ay, A.A.; El-Ezz, S.F.A. Performance of 'Flame seedless' grapevines grown on different rootstocks in response to soil salinity stress. Sci. Hortic. 2021, 275, 109704. [CrossRef] 